\title{
Matjaž RAZISKAVE BESEDNEGA BABIČ REDA V STARI GRŠČINI
}

Izvleček

C̆lanek vsebuje pregled poglavitnih vprašanj, s katerimi se srečamo, kadar preučujemo besedni red v korpusnem jeziku. Pogoji za tovrstno raziskavo so $\mathrm{v}$ grščini razmeroma dobri, saj je na voljo dovolj raznovrstnih besedil. Težave nastopijo, ker gradivo ne ustreza docela pojmovnemu orodju, kot ga uporabljamo pri raziskavah besednega reda živem jeziku - kjer se lahko vselej zanesemo na naravne govorce -, zato so večino raziskav $v 20$. stoletju zaznamovali izraziti metodološki premiki.

\section{Abstract}

When a modern linguist is confronted with a corpus language, new challenges are to be met. Linguistic material that has been preserved to us in case of Ancient Greek is voluminous, it also includes texts of a broad stylistic range. The main difficulty is represented by the fact that one can not rely on the same methods that one would apply to a word order research in a modern language where, as the last resort, native speakers exist that can be consulted. It is therefore no surprise that a search for an applicable method was a prominent feature of most modern linguistic researches of the word order in Ancient Greek.

\section{Besedni red v korpusnih jezikih - težave in prednosti}

Že pravi pravcati topos v razpravah o besednem redu v grščini je naštevanje težav, ki jih imamo, če iščemo pravila, po katerih se ravna besedni red v mrtvem jeziku oz. tistem, čemur se po nemško reče Korpussprache:

- Na voljo imamo besedila, a nikogar, ki bi ga lahko vprašali, v kako dobrem jeziku so napisana in ali se je tudi v resnici tako govorilo, kakor je napisano.

- Ne vemo, ali so jezikovna sredstva, ki so uporabljena vohranjenih besedilih, vsa sredstva, kar jih je tisti jezik poznal, ali je bilo morda še kaj drugega, za kar ne vemo.

- Če se naučimo jezika in v njem napišemo besedilo, ne bo nikogar, ki bi nam zanesljivo povedal, ali se nam je posrečilo ali ne. 
Vse to in še veliko drugega bi se dalo našteti, če bi hoteli biti izčrpni. Delo $\mathrm{z}$ besedili v mrtvem jeziku je težko povsod, vendar ponekod bolj, drugod manj. V veliko pomoč nam je, če so besedila slogovno in zvrstno različna ter če sojih pisali različno izobraženi pisci. Načeloma obstaja pri takem jeziku celo možnost, da se bo odkrilo še kaj novega in bomo lahko tam preizkusili, kar smo ugotovili na podlagi že prej znanega gradiva. In vse te dobre lastnosti ima prav stara grščina.

- Besedil je razmeroma veliko. ${ }^{1}$

- Gradivo je tako raznovrstno, kot je sploh lahko: od največjih besednih umetnin in premišljene filozofske proze do uradnih listin in (resda redkih) zasebnih pisem ljudi, ki so komajda znali pisati.

- Skoraj vse to gradivo je zgledno objavljeno, tako da je dostopno $v$ knjižni, dandanes celo v elektronski obliki vsakomur, ki se zanima zanj.

- Od časa do časa se odkrije še kaj novega. V Egiptu in Pompejih pride skoraj vsako leto na dan kakšen nov papirus. Ni še 50 let, odkar sta Ventris in Chadwick razvozlala linear B in nam omogočila, da si lahko ogledamo besedila v grščini, ki so najmanj 300 let starejša od Homerja.

- Še vedno je živa mlajša oblika tega jezika, ki je stari dovolj podobna, da si lahko pomagamo z njo.

V stari grščini se torej pravzaprav nimamo kaj pritoževati. Če bi se v katerem mrtvem jeziku glede na ugodne zunanje okoliščine dalo kaj ugotoviti, bi se moralo v stari grščini.

\section{II. Čemu naj bi se danes s tem še vedno ukvarjali?}

Razloge za to, da se še danes ukvarjamo z besednim redom v stari grščini, bi lahko razdelili v naslednje skupine:

1. S slogovno obdelavo besedila bi lahko ugotovili, kakšen vtis je hotel pisec narediti na bralce oziroma govornik (če imamo opraviti z govorom) na poslušalce. Zato je vsekakor dobro vedeti, ali so besede razporejene tako, kot bi bile v neumetniški različici istega besedila - če si lahko tako predstavljamo.

2. Zaradi besednega reda v novi grščini. Ta je sicer še vedno prost, a ga vseeno uravnava kar nekaj pravil, ki kažejo, da ni vseeno, kje kaj stoji. V nekaterih lastnostih je precej podoben besednemu redu v romanskih jezi-

1 CD-ROM Thesaurus Linguae Graecae, na katerem je zbrana večina besedil grške antike, vsebuje v najnovejši izdaji podatkov-besedil za $614 \mathrm{MB}$ (in to v precej skrčeni obliki, $v$ kateri zavzamejo naglasi in pridihi manj prostora kot ponavadi). Za primerjavo: CD-ROM z rimsko književnostjo (resda samo do 2. st. po Kr., torej brez patristike) ima besedil za $95 \mathrm{MB}$. 
kih, predvsem po tem, da je treba mesto stavčnega predmeta (objekta), če ga prestavimo na začetek stavka, zavarovati $\mathrm{z}$ osebnim zaimkom:

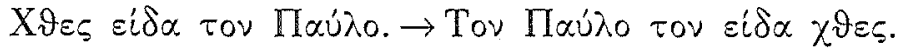

Po tem se vidi, da velja zveza osebek-povedek-predmet za okostje z ustaljenim zaporedjem sestavin in da gre pri postavljanju predmeta $\mathrm{v}$ tem primeru za izpostavljanje, se pravi za izločanje iz ustaljene zgradbe. Če bi vedeli več o besednem redu v stari grščini, bi lahko bolje ocenili obseg in globino sprememb, ki so nastopile v srednjem veku. ${ }^{2}$

3. Zaradi pogleda nazaj proti indoevropščini. Kljub razumljivim težavam in zapletom so na tem področju precej dosegli zlasti v tipoloških raziskavah (Lehmann 1974) in $v$ raziskavah s sredstvi, ki jih nudi na razpolago pretvorbena slovnica (Krisch 1994). Oboji domnevajo, da je obstajala za besedni red $v$ indoevropščini osnovna stava, ki se jo je dalo pod različnimi pogoji različno spreminjati. Predvsem tipološka opredelitev izhaja iz predpostavke, da je bila indoevropščina jezik z zelo bogatim oblikoslovjem in da je za tak jezik bolj smiselna stava glagola bolj proti koncu stavka, greenbergovsko rečeno torej SOV. Taki predpostavki ni moč ničesar očitati in se zdi čisto zmerna. ${ }^{3}$ Nerodno je le, da je v luči nekaterih novejših raziskav videti, da bi si lahko stanje $\mathrm{v}$ indoevropščini predstavljali tudi drugače. $\mathrm{V}$ priročniku Matasović 1997 (237 ss.) npr. naletimo na zelo prepričljivo razloženo domnevo, da oblikoslovna ureditev indoevropščine ni bila tako razvejana, kot jo najdemo v grščini ali stari indijščini. 4 Če je bilo res tako, potem se najbrž tudi ne da tipološko utemeljevati domnevnega osnovnega zaporedja SOV. Prav tako je iz tega zornega kota presenetljivo, da je glagol v latinščini veliko pogosteje na koncu stavka, čeprav ni bilo latinsko oblikoslovje nikoli tako bogato kot grško.

\section{Ustaljen ali stalen besedni red?}

Kot je bilo že rečeno, je ena od slabih strani tipološke metode, da mora za indoevropščino predpostavljati nekaj, za kar se ne ve, ali je bilo res tako. Druga slaba stran je - ta ji je skupna s pretvorbenim pristopom -, da

2 V besedišču je videti, da je bila grščina ob koncu antike že precej blizu današnjemu stanju. O tem najbolje priča nedavno izšli grško-slovenski slovar novozavezne grščine, ki ga je pripravil Miran Špelič (Špelič 2002). Je bilo morda tako tudi pri besednem redu? $\mathrm{Za}$ bizantinske pisce je to zelo težko ugotoviti, ker se zelo togo držijo sloga antičnih piscev.

3 Jasno je predstavljena v delu Cuzzolin 1994, str. 48s.

4 Na to lahko v grščini sklepamo po obnašanju ženskega spola in po glagolskih končnicah, ki na najstarejši, gotovo še predmikenski stopnji kažejo nenavadno enotnost in zelo malo razlik med glavnimi in stranskimi končnicami. 
mora izhajati iz osnovnega obrazca, ki se lahko spreminja samo v določenih okoliščinah. 5

Tukaj pride na plan še ena past, v katero se je zelo lahko ujeti. Ker sta vloga in naloga besednega reda od jezika do jezika različni in ker ju je ponavadi zelo težko natančno opisati, je tisti, ki se ukvarja $z$ besednim redom v mrtvem jeziku, ves čas v nevarnosti, da podleže predsodkom svoje materinščine, da začne torej pričakovati od besednega reda v mrtvem jeziku tisto, kar mu daje besedni red v materinščini. Pri oblikoslovju se to zgodi veliko redkeje: končnica je (vsaj v indoevropskih jezikih) končnica, predlog je predlog, veznik je veznik. Tam se ne da zmotiti. Toda pri besednem redu je velikokrat drugače: predvsem tipološko usmerjena raziskava se velikokrat znajde v položaju, ko mora primerjati stvari, ki so si podobne samo na videz. ${ }^{6}$ Torej pomeni - če govorimo v duhu tistega, kar pravi Martinet (Martinet 1985, 79) - primerjati besedni red v slovenščini in besedni red v angleščini ter ugotoviti, da je v obeh jezikih SVO, ravnati tako, kot če bi znotraj slovenščine primerjali zaporedje oblikotvornih prvin znotraj besede $\mathrm{z}$ zaporedjem besed $\mathrm{v}$ stavku:

I. Druar seka drua.

II. $d r v-a r-\varnothing$

$\mathrm{S} \quad \mathrm{V} \quad \mathrm{O} \quad$ koren pripona končnica

$\checkmark$ prvem primeru lahko zaporedje spremenimo ali vmes vrinemo druge besede, $v$ drugem primeru ne moremo ne enega ne drugega.

A zgornji primer je vendarle nekoliko pretiran. Vsekakor imamo poleg popolnoma prostega besednega reda in skladenjsko popolnoma določenega besednega reda še tretjo možnost, to je ustaljeni besedni red, ki sam po sebi ni edino znamenje slovnične vloge. Sem bi lahko šteli npr. v slovenščini stavo pridevniškega prilastka pred samostalniškim jedrom ali $v$ nemščini položaj glagola na koncu odvisnega stavka: če ga ne damo na konec, to sicer ni prav, ampak glagol zavoljo tega še vedno ostane glagol in odvisni stavek je še vedno odvisni stavek. Tukaj spet tiči enaka past, le da je še bolje skrita kot prej: iz materinščine samo vajeni, da je besedni red vsaj deloma ustaljen, ne da bi bil sam po sebi edino jamstvo za slovnično vlogo (funkcijo), zato nevede pričakujemo, da je bilo tako tudi v mrtvem jeziku. Tako si človeku, ki je vajen v odvisnem stavku postavljati glagol vedno na konec, ne zdi nič čudnega, da je tako tudi v latinščini. Po drugi strani tisti, v čigar jeziku igra veliko vlogo pri besednem redu členitev po aktualnosti, spet zase pričakuje, da je bilo tako tudi v mrtvem jeziku, in se, ko opazuje besedni red, nevede zanaša na tovrstno členitev.

Če predpostavljamo, da je bil besedni red ponekod ustaljen, se moramo zavedati, da je to zgolj predpostavka. Zato bi se morali že vnaprej odpovedati t. i. osnovnim vzorcem ali celo obrazcem, ki bi jih pustili neobdela-

5 O tem podrobno Cuzzolin (1997).

6 Ali, kot bi tudi lahko rekli, na površini. 
ne in se o njih ne bi spraševali naprej. Tudi tukaj se splača upoštevati priporočilo, ki ga daje - čeprav tam ne govori prav posebej o besednem redu - Martinet (1985, 72). ${ }^{7}$

\section{Grška pričevanja}

Kako daleč bomo lahko prišli? Tudi ko bi vedeli vse, bi si s tistim najbrž lahko pomagali samo toliko, kolikor si je lahko pomagal takratni Grk.

O Platonu piše Dionizij Halikarnaški (De compositione verborum 25, 210 214) naslednje:

Platon svojih dialogov ni nehal česati, kodrati in na vse načine prepletati niti, ko je bil star osemdeset let. Nedvomno je usem učenjakom poleg drugega, kar priča o natančnosti tega moža, znano tudi tisto o tablici, ki so jo baje našli po njegovi smrti in na kateri je bil večkrat spremenjen tale začetek Države: »Vceraj sem šl dol v Pirej skupaj z Glavkonom, Aristonovim sinom «.8.

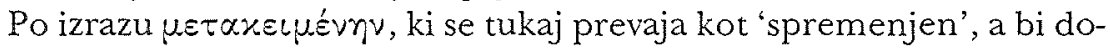
besedno pomenil 'prestavljen, premeščen' lahko sklepamo, da je prestavljal besede in iskal različico, ki je najlepše zvenela. Položaj torej, v kakršnem se je gotovo že kdaj znašel vsakdo od nas, ko je hotel napisati kaj, za kar je hotel, da bi se lepo slišalo.

\section{Oblikovanje besedila - zavestna dejavnost?}

Skoraj se ne da dovolj glasno opozoriti, kako zelo previden mora biti vsakdo, ko presoja način, na katerega so pisali Grki, in si ga prizadeva razumeti. Za ponazoritev bi lahko omenili dve mesti: eno iz Aristotelove Poetike in drugo iz Dionizija Halikarnaškega.

Ko Aristotel v Poetiki zelo na kratko govori o jezikovnih prvinah, našteje besedne vrste, skuša opredeliti, kaj pomenijo, kajje oblika ( $\pi \tau \tilde{\omega} \sigma \iota \varsigma)$, kaj so tvorjenke, kaj je barbarizem itd. Vse, kar pove tam, spada po naši današnji predstavi $\mathrm{v}$ oblikoslovje. Na skladnjo, ki bi po naši predstavi o

7 Tout le descripteur a le droit et le devoir de définir, pour une langue donnée, un type particulier de groupement de signes minimum, si la nature des faits décrits recommande une présentation particulière. Mais ceci, bien entendu, ne justifierait pas l'emploi du nouveau concept dans la description de n'importe quelle autre langue.

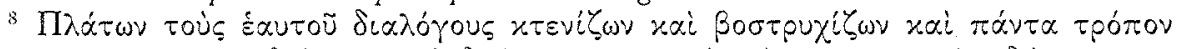

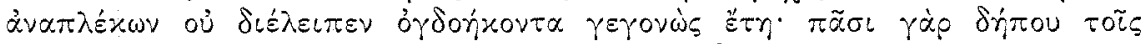

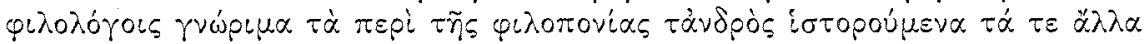

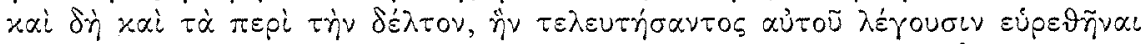

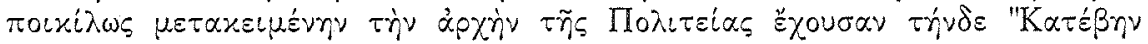

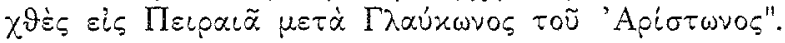


slovnici morala slediti, Aristotel ni pozabil, temveč je nalašč ni obravnaval skupaj z oblikoslovjem. To celo izrecno utemeljuje (Poet 1456b (8-20)):

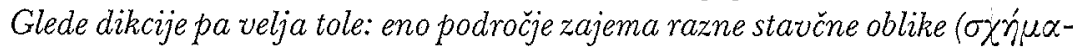
$\tau \alpha)$, torej vprašanja, kakšna je razlika med ukazom, prošnjo, pripovedjo, grožnjo, vprašanjem, odgovorom in podobno. To področje mora obvladati bolj igralec in pa kdor se ukvarja s preučevanjem igralske umetnosti (üo-

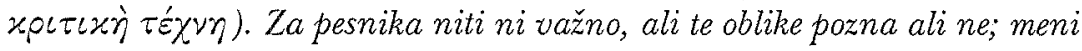
vsaj ni znana nobena omembe vredna kritika poezije, ki bi izhajala s tega stališc̆a. Kaj naj si na primer mislimo o Protagoru, ki je kritiziral Homerja, češ da je v verzu »Pesem, boginja, zapoj o jezi ... « hotel nekaj prositi, v resnici pa je ukazoval? Protagoras namreč trdi: če komu zapoveš ali prepoveš nekaj storiti, tedaj je to ukaz. To vprašanje torej ni predmet pesniške, ampak druge umetnosti; zato ga opustimo!'

Jezik (morda bi prej rekli 'slovnico') si Aristotel torej predstavlja izključno kot nauk o glasovih (črkah) in besednih vrstah; za prvine, ki bi jih danes šteli v skladnjo, pravi, da spadajo v nauk o uprizarjanju ('o [sprotnem] izražanju'). Skladnja je torej po njegovem spadala v področje zavestnega oblikovanja besedila in ne na področje slovnice. Zato se je ta snov tudi v šolah prepuščala pouku govorništva, ki je sledil jezikovno-slovstvenemu pouku, se pravi, da je bila skladnja prepuščena učitelju govorništva. Jezikovni poukje pismenemu izražanju vtisnil močan pečat 10 , drugega mu je vtisnila že od davnine živa govorniška dejavnost. V grških šolah so se otroci učili predvsem oblikoslovja (besedne vrste), v tem duhu je potekal tudi hkratni pouk slovstva. Skladnja je bila v veliki meri prepuščena - kot bi rekli danes - višjim razredom, vendar se tam niso učili govoriti, ampak javno nastopati, zato je bilo spet močno poudarjeno zavestno jezikovno ustvarjanje. In ker je bil najpozneje od Gorgije in drugih sofistov pri govorništvu v ospredju glasovni učinek - čeprav so o filozofi temu ves čas močno nasprotovali -, je moral grški govornik včasih način, včasih celo vsebino izražanja podrediti glasovni podobi. Perioda ni bila samo vsebin-

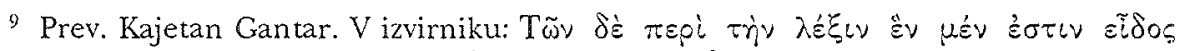

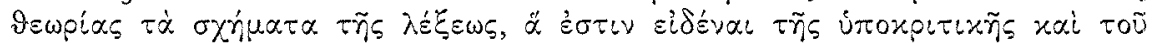

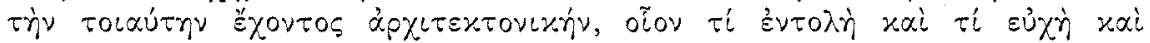

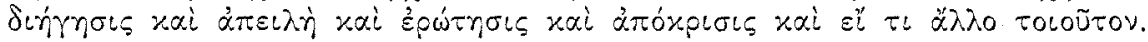

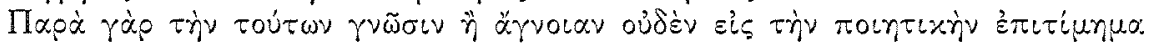

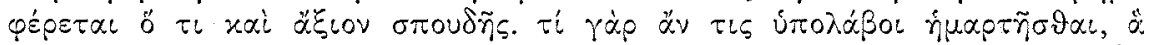

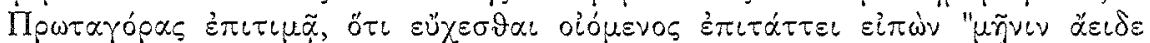

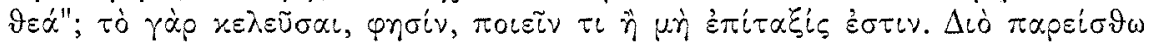

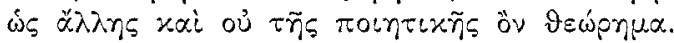

$10 \mathrm{Ne}$ trdimo, da bi bilo danes kaj drugače: kot primer navedimo češki učbenik skladnje za osnovno šolo (Hauser 1973), v katerem pisec opozarja učitelje, naj pri izbiri primerov, ki jih bodo pisali na tablo, ne uporabljajo vedno stavkov tipa Oče seka drua, ker s tem pri učencih zbudijo vtis, da mora biti na začetku stavka vedno osebek. 
ska enota, ampak tudi in predvsem zvočno zaokrožena celota - besed je moralo biti toliko, da se je krog sklenil. Še toliko bolj, ker daje grščina s svojim razvitim oblikoslovjem veliko možnosti za to. Odnos učiteljev govorništva do teh vprašanj lepo ponazarja že imenovani Dionizij Halikarnaški (De compositione verborum 2,19-26):

Edino, kar bi bilo treba povedati o povezovanju besed, je to, da splet in postauljanje skupaj treh, štirih ali kolikor koli že besed naredi t. i. člene $(\varkappa \tilde{\omega} \lambda \alpha)$, nato njihovo sozvočje izpolni t. i. periode, te pa tvorijo celotno besedilo. Naloga povezovanja je ustrezno postaviti besede drugo ob drugo, dati členom primerno sozvočje in besedilo dobro razdeliti na periode. ${ }^{11}$

Tudi tukaj torej ni več govora o kakršnih koli natančnih pravilih, ki naj bi to uravnavala, omenja se (celo dvakrat) edinole 'sozvočje' (ápuovía). Kot vidimo, je torej odločal je predvsem slušni vtis.

Še en odlomek iz Dionizija Halikarnaškega nam kaže, da si je oblikovanje besedila predstavljal kot zavestno dejavnost. Tako npr. takrat, ko govori o slogu v nevezani besedi, vzame za zgled naslednji odlomek iz Herodota (Hist 1, 6, 1-5). Odlomek najprej podaja tako, kotje pri Herodotu (le da ga nekoliko prilagodi atiškemu narečju), nato ga po svoje priredi v dveh različicah

\section{Po Herodotu:}

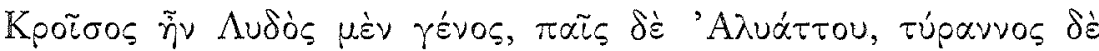

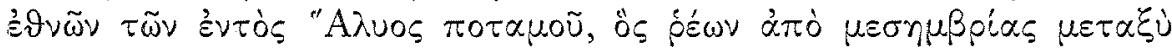

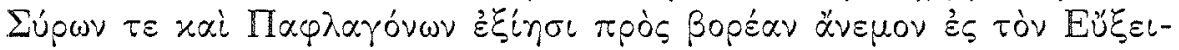

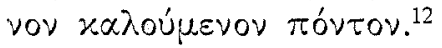

Za ta način pisanja pravi (4.63), da je »počasi izpeljujoč« (ย́ $\pi \alpha \gamma \omega \gamma \iota-$

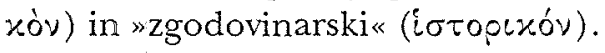

\section{Različica 1:}

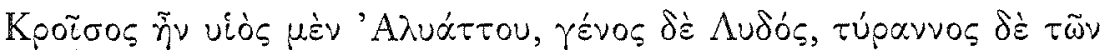

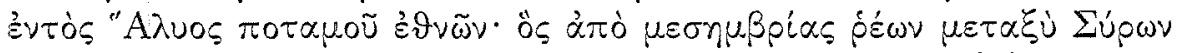

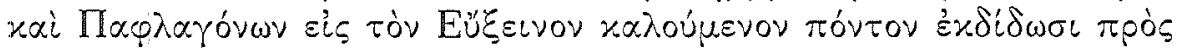
Bopéav ăveuov.

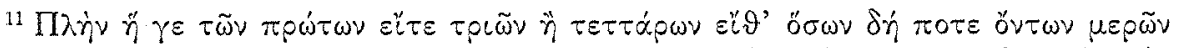

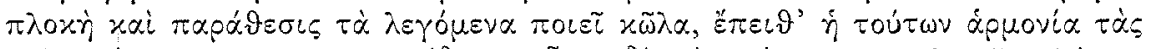

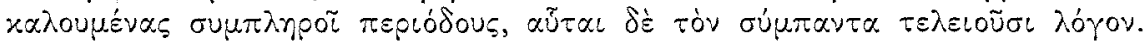

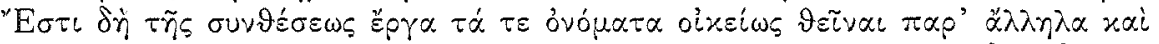

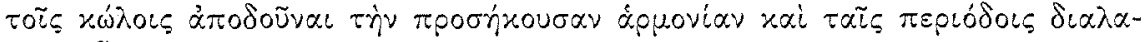

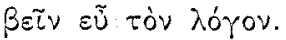

12 Prevod: „Krez je bil po rodu Lidijec, Aliatov sin, tiran ljudstev tostran reke Halis, ki teče od juga med Sirijo in Paflagonijo ter se izliva na severu v t. i. Črno morje." 


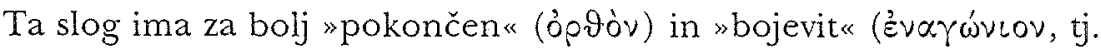
primeren za sodni govor). Za ta slog je spremenil naslednje:

- namesto samostalnika $\pi \alpha \tilde{\iota} \varsigma$ je uporabil atiško ustreznico viós;

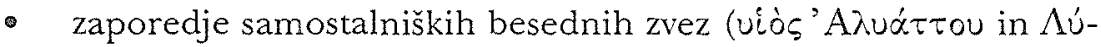

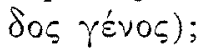

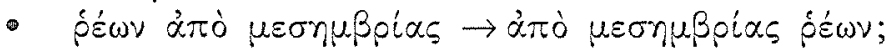

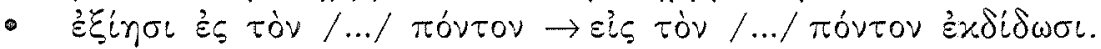

Dopolnilo kraja je torej dvakrat postavil pred glagol, od katerega je odvisno, medtem ko je bilo prej za glagolom.

Različica 2:

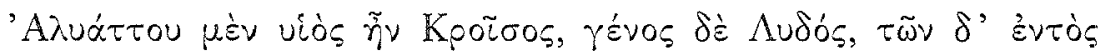

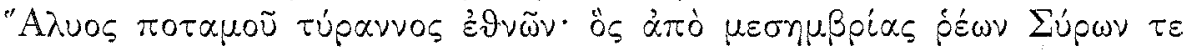

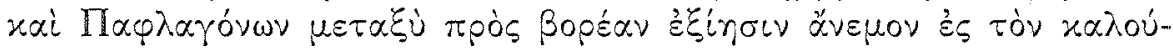

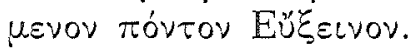

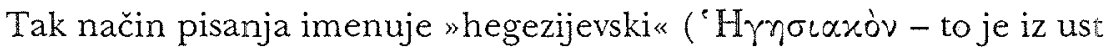
prepričanega aticista Dionizijevega kova najhujša obtožba, kar jih je), „giz-

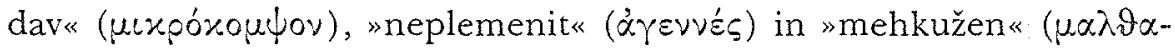
xóv). Za ta slog je besedilo predelal še malce bolj kot prej:

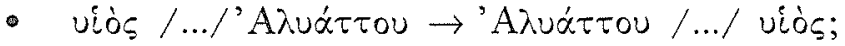

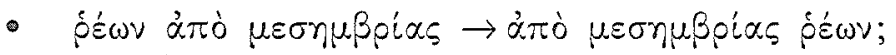

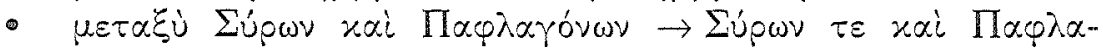
róvav $\mu \varepsilon \tau \alpha \xi \dot{\text {; }}$

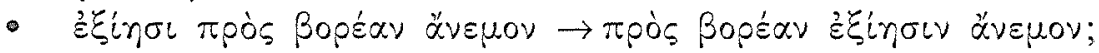

Pri tem slogu je enkrat spremenil besedni red v samostalniških besednih zvezah in drugo besedno zvezo razcepil.

Pred sabo imamo torej tri različice. Vse so bile očitno možne, a Dionizij pravi samo, da je ena primerna za zgodovinarja in druga za sodni govor, medtem ko o tretji izvemo komaj kaj več kot to, da mu ni všeč. Niti besede o tem, katera od njih je bližja govorjenemu jeziku, ali vsaj, kateraje najbolj oddaljena od njega! Tudi v opisu druge različice ỏplóv gotovo ne pomeni 'pravilno'. Dioniziju Halikarnaškemu gotovo ne moremo oporekati, a še vedno ne vemo, kateri od teh slogov je bil tak, kot so govorili ljudje med sabo v vsakdanjem pomenku. Ker od antičnih piscev ne dobimo podatkov, bi morali torej »osnovni vzorec«, če bi ga hoteli imeti, postaviti sami, ne da bi se mogli naslanjati na izrecno potrditev naravnega govorca.

Od Grkov samih torej ne dobimo nobenega dokončnega odgovora, čeprav se je ohranilo kar nekaj del, kjer bi ga lahko našli. Zato nam tudi dandanes ne preostane nič drugega, kakor raziskovati besedni red tako, kot da ne bi imeli od Grkov ničesar posebej napisanega o tem. Nič čudnega ni torej, da so raziskave besednega reda v 20 . stoletju potekale $v$ dokaj različne smeri. 
VI. Raziskave v 20 . stoletju $^{13}$

Razprava o položaju predmeta in povedka (dvajseta in trideseta leta 20. stoletja)

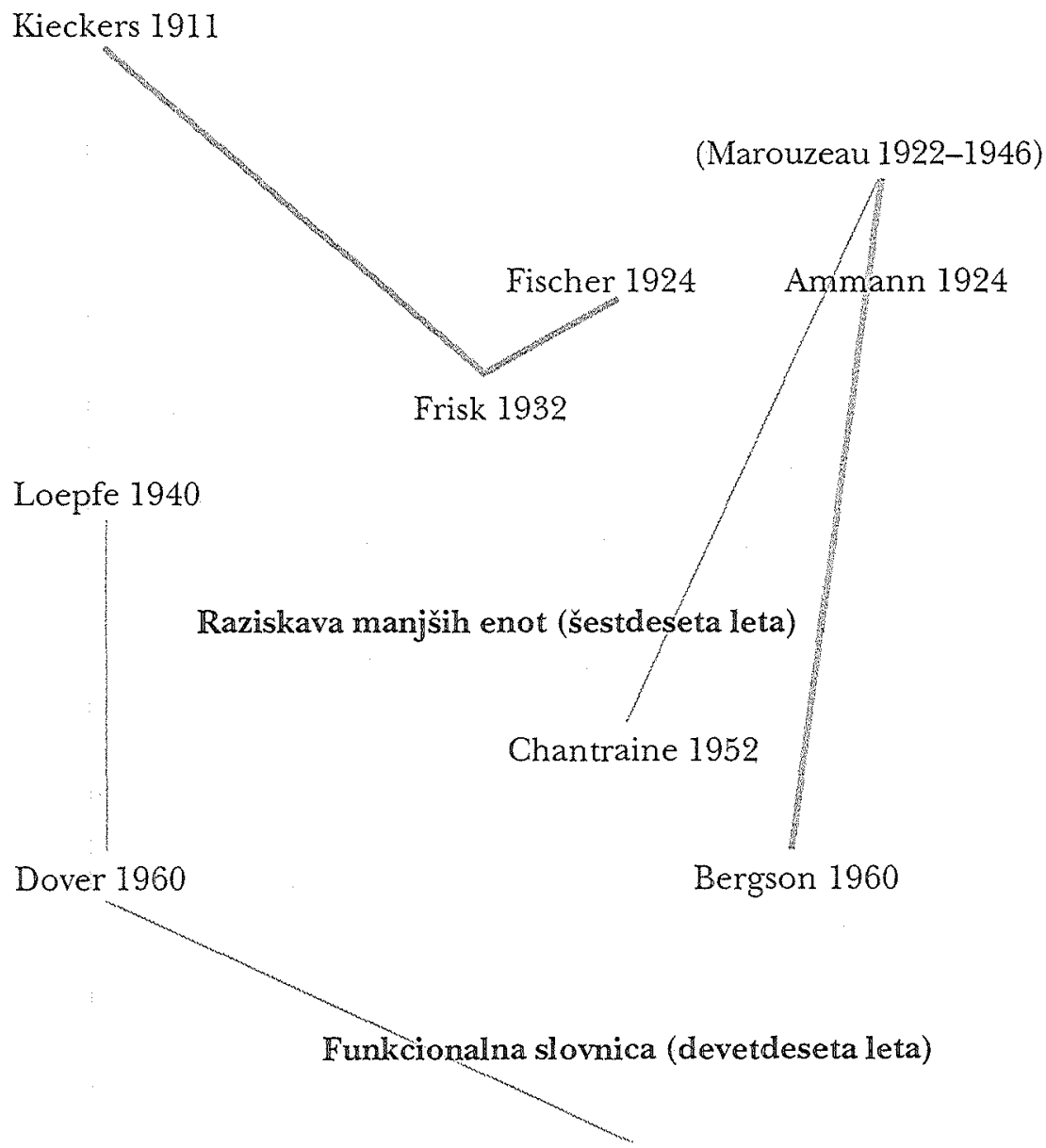

Dik 1995

Cuzzolin 1997

${ }^{13}$ Opombe k preglednici:

- Debela črta: pisec se je neposredno naslanjal na drugega in uporabljal izide njegove raziskave.

- Tanka črta: drugi pisec se je na prvega naslanjal samo $v$ podrobnostih in ne $v$ celoti. 
Kot vidimo iz preglednice, so se raziskave v prvi polovici 20. stoletja vrtele okrog vprašanja, ki ga zaznamujeta nemška izraza Mittelstellung in Endstellung. Beseda je tekla o stavi glagola, čeprav je šlo v resnici bolj za stavo predmeta glede na glagol. Razpravo je s svojo knjigo vzpodbudil Kieckers, ki je menil (kot se vidi iz preglednice), da je 'normalni položaj' grškega glagola sredi stavka, tako da je predmet za njim. Po 2. svetovni vojni mu je v reviji Glotta odgovoril Fischer in predvsem na podlagi besednega reda v pregovorih dokazoval, da je običajni položaj glagola na koncu stavka ali vsaj za predmetom. Spor je do določene mere pomiril Frisk s svojo knjigo, ki je izšla osem let pozneje. Nagibal se je sicer k Fischerjevim trditvam (kot se vidi iz preglednice), a s statistično naravnano raziskavo trditev predhodnikov ni mogel ne dokončno potrditi ne ovreči.

Nekoliko ob strani je ostala Ammanova razprava o besednem redu pri Homerju. Ni zbudila tolikšnega odmeva, kot bi si ga zaslužila, deloma tudi zato ne, ker se je pisec ukvarjal s Homerjem, torej s pesniškim besedilom, in ker je imela v naslovu poleg besednega reda še stavčno zgradbo. Pri Homerju se o enem pač ne da govoriti brez drugega. Ni neposredno sodeloval v sporu o stavi glagola, čeprav je gotovo imel do njega določeno stališče. Ker je izhajal iz predpostavke, da je glagol na koncu stavka, se je moral soočiti z neprijetno resnico, da pri Homerju ni vedno tako. Da bi lahko razložil tudi take primere, je prvič v raziskavah grškega besednega reda ločeval med obveznimi in neobveznimi sestavinami. Nujne sestavine, torej glagol z obveznimi dopolnili $(S, O)$ je imel za Kemsatz, v katerem je glagola praviloma na koncu. Ostalo je imenoval 'razširitve in dodatki' (lose angefügte Erweiterungen). Te da se lahko po potrebi razporejajo okrog jedrnega stavka (ali 'stavčnega jedra') glede na zunanje dejavnike. Njemu in Frisku lahko pripišemo tudi, da sta ugotovila, da veljajo za stavo t. i. 'glagolov ustaljenega postopka' (prozesuelle Verben) očitno drugačna pravila kot za ostale glagole.

Po Friskovi knjigi je razprava za nekaj desetletij potihnila. Brez večjega odmeva je ostalo Loepfejevo delo Besedni red v grškem govomem stavku, ki je nastalo kot disertacija na švicarski univerzi Freiburg. Loepfe navezuje na psiholingvistiko 19. stoletja in loči psihološki subjekt in psihološki predikat, uporablja tudi izraza tema in rema, vendar obravnava členitev precej formalistično in skuša iz teh deh osnovnih sestavin izdelati stavčne tipe.

V letih po 2. svetovni vojni je prvo pomembnejše delo Chantraineov članek, vendar se ga ni veliko bralo, ker je izšel v manj znani reviji Anales de

- Razporeditev: na desni strani so tisti, ki menijo, da je povedek bolj na desni. Na levi so tisti, ki menijo, da v osnovnem obrazcu povedek ni nujno na desni strani (proti koncu stavka).

- Marouzeaujevo delo je navedeno v oklepaju, ker obravnava besedni red v latinščini. 
filología clásica, ki je izhajala v Buenos Airesu. Ta se poleg splošnih oznak naslanja na Marouzeaujevo delo (v štirih knjigah, zadnja je izšla 1946) o besednem redu v latinščini. Besedni red se je spet znašel v ospredju po letu 1960, ko sta hkrati izšli dve zelo pomembni deli: Bergsonova knjiga o stavi pridevnika v grški prozi in Doverjeva o besednem redu. Bergson se je po načinu dela močno naslanjal na že omenjeno Marouzeaujevo knjigo o tem vprašanju v latinščini, torej je raziskoval stavo pridevniškega prilastka predvsem glede na pomen. Marouzeau je za latinščino namreč ugotovil, da tam načeloma stoji vrstni pridevnik za samostalnikom in kakovostni pridevnik pred njim. Bergson je začel s predpostavko, da je v grščini enako, a mu je pri tovrstni opredelitvi ostalo precej primerov nerazporejenih. Tudi vzorec je bil manjši: v latinščini lahko načeloma kateri koli pridevnik stoji pred samostalnikom ali za njim, medtem ko velja to v grščini samo za besedne zveze brez (določnega) člena. ${ }^{14}$ Opazil je, da se pridevnik dostikrat zapostavlja takrat, kadar je znan iz sobesedila, da se torej nekako navrže.

Po naključju je ravno istega leta Kenneth Dover objavil svojo knjigo o besednem redu, ki še danes velja za prelomno delo. Dover je besedni red raziskoval najprej na dvobesednih stavkih, nato je od krajših prehajal $\mathrm{k}$ daljšim in prišel do enakega sklepa kot Bergson. Važno je, ali je bilo kaj omenjeno že prej - tisto se nato zapostavlja.

$\mathrm{Na}$ Doverjevo delo se, čeprav samo posredno, navezuje zadnja (meni znana) knjiga o besednem redu v grščini. To je doktorska disertacije Helme Dik $z$ naslovom, kot je naveden v tretjem delu izročka. Avtorica se je besednega reda $v$ grščini lotila $z$ metodološkega izhodišča t. i. funkcionalne slovnice, ki ima zlasti veliko pristašev na Nizozemskem. Funkcionalna slovnica se $z$ besednim redom ukvarja zelo veliko in pričakovati je bilo, da bo kdo izmed njih obdelal tudi grščino. Njena naloga se vsaj posredno navezuje na Doverja. ${ }^{15}$ Kakor smo lahko po eni strani navdušeni nad njeno izčrpnostjo, je vendarle težko dojeti nekatera metodološka izhodišča funkcionalne slovnice, med drugim predvsem dvoje:

1. tesno združevanje skladnje in pragmatike;

2. velik poudarek na besednem pomenu.

Najprej o prvem: ne moremo si kaj, da ne bi opazili, da je ta slovnica nastala na germansko govorečem področju. Osnovni obrazec, kot ga ima na str. 12:

P1 $\quad P \varnothing \quad \mathrm{V} \quad \mathrm{X}$

(pri čemer pomeni $\mathrm{P} 1$ - topic, $\mathrm{V}$ - verb, $\mathrm{P} \varnothing$ - focus in $\mathrm{X}$ - position of the remaining elements)

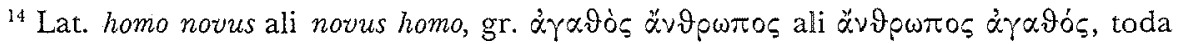

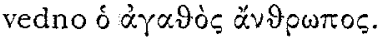

${ }^{15}$ Ta je bil pri njeni disertaciji nekakšen pridruženi član komisije za oceno. 
kaže, da se glagol ob tem načinu dela izvzema iz aktualnostne zgradbe, čeprav avtorica priznava, da igra lahko tudi vlogo topic ali focus.

Glede drugega bi bili pomisleki bolj o izbiri gradiva. Besedni red obravnava tako, da si vzame nekaj glagolov, ki pri Herodotu pogosto nastopajo,

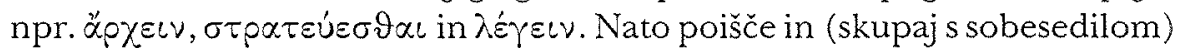
izpiše odlomke, kjer ti nastopajo, ter raziskuje, kako se stavki prilegajo predloženemu stavčnemu vzorcu. Do te stopnje gre še kar dobro, a v zadnjem delu knjige, ko skuša izsledke uporabiti za razlago daljših sklenjenih odlomkov, je odgovor kar prevečkrat »Ne vem, zakaj je tako« (npr. str. 245).

\section{Besedni red v mikenski grščini}

Odkar je bil razvozlan linear B, je bilo upati, da bodo mikenske tablice o tem povedale kaj več. Konec koncev so toliko starejše od Homerja, da bi lahko kazale tudi starejše stanje glede besednega reda. Dodatna dobra stran je tudi, da besedila na njih niso čisto nič umetniška. A po drugi strani so zelo kratka in tako zgoščena, da se iz njih ne da ugotoviti skoraj nič. O tem že od prve polovice sedemdesetih let izhajajo članki. ${ }^{16} \mathrm{Na}$ žalostje bila. o tem napisana samo ena knjiga ${ }^{17}$, a upati je, da bo kmalu izšla še katera. Pokazalo se je, da ni v mikenski grščini z besednim redom nič drugače kot v klasični. Celo v tako kratkih zapiskih, kot so na tistih tablicah, najdemo različice, podobne tistim, ki se je z njimi igral Dionizij Halikarnaški, npr. v paru, v katerem je drugi zapisa popravljena različica prvega:

Eb 416 u-wa-mi-ja te-o-jo do-e-ra e-ke-qe i-je-re[-ja] ke-ra o-na-to

Ep 704.2 u-wa-mi-ja te-o-jo do-e-ra o-na-to e-ke i-je-re-ja ke-ra

Edina razlika je, kot vidimo, v vezniku qe $(=\tau \varepsilon)$, vendar ni moč razložiti, kako naj bi ta vplival na stavo povedka.

\section{Kako naprej?}

Kot je moč sklepati iz vsega, kar je bilo povedano, se besednega reda v grščini ne da (in se najbrž tudi nikoli ne bo dalo) do konca razložiti $z$ osnovnim vzorcem, zato je zelo težko delovati po znanstvenih načelih, ker ne vemo, kaj bi vzeli za predpostavko. Poleg tega je veliko teže sestavljati statistiko, če ne veš, kaj pravzaprav pričakuješ. To se lepo vidi iz razprave o predmetnih odvisnikih (Cristofaro 1997), kjer se statistično naštevajo primeri, pri katerih je precej opredelitev vprašljivih.

\footnotetext{
${ }^{16}$ V Franciji je takrat nastala celo magistrska naloga o tem, a mi žal ni uspelo priti do nje.

17 Babič 1997.
} 
Vsekakor bi bilo dobro pristopu, ki upošteva členitev po aktualnosti in pragmatiko, dodati še pristop iz smeri besediloslovja, ki bi izhajal iz sklenjenega besedila ali daljšega odlomka. Prav tako bi se dalo ugotoviti, kako se obnašajo »navržene « sestavine, torej tisto, kar je iz prej povedanega že znano, a se vseeno ne izpusti.

\section{LITERATURA}

AMMANN, H. (1922): Untersuchungen zur homerischen Wortfolge und Satzstruktur. Freiburg.

ARISTOTELES: Poetika. Druga, dopolnjena izdaja, prev. Kajetan Gantar. Ljubljana 1982.

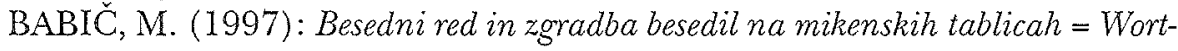
stellung und Textgestaltung auf den mykenischen Linear-B-Tafeln. Ljubljana 1997.

BERGSON, L. (1960): Zur Stellung des Adjektivs in der älteren griechischen Prosa. Stockholm.

BANFI, E. (1997): Studi di linguistica greca II. Pavia (Materiali linguistici Università di Pavia).

CHANTRAINE, P. (1952): Recherches sur l'ordre de mots en grec. AFC 71 ss.

CRISTOFARO, S. (1997): Aspetti semantici e pragmatici della distribuzione dio

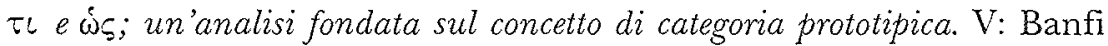
(1997), 57-70.

CUZZOLIN, P. (1994): Sull'origine della costruzione dicere quod: aspetti sintattici e semantici. Firenze.

CUZZOLIN, P. (1997): Alcune considerazioni sull'ordine delle parole in greco classic. V: Banfi (1997), 71-106.

DIK, H. (1995): Word Order in Ancient Greek: A Pragmatic Account of Word Order Variation in Herodotus. Amsterdam (Amsterdam Studies in Classical Philology).

DOVER, K. (1960): Greek Word Order. Cambridge.

DUHOUX, Y. (1975): L'ordre des mots en mycénien. Minos 14 (1975), 123163.

DUNKEL et al. (1994): Dunkel, G. E.-Meyer, G.-Scarlata, S.-Seidl, C. (edd.): Früh-, Mittel-, Spätindogermanisch, Akten der IX. Fachtagung der Indogermanischen Gesellschaft vom 5. bis 9. Oktober 1992 in Zürich. Wiesbaden 1994.

FISCHER, P. (1924): Zur Stellung des Verbums in Griechischen. Glotta 13, 1-10.

HAUSER, P. (1973): Skladba na základni devítileté škole. Praga 1973.

KIECKERS, E. (1991): Die Stellung des Verbs im Griechischen und in den verwandten Sprachen. Strassburg. 
KRISCH, T. (1994): Beobachtungen zur Wortstellung im Altindischen. V: Dunkel et al. (1994), 169-183.

LEHMANN (1974): Proto-Indo-European Syntax. Austin-London 1974.

PANAGL, O. (1973): Eine Wortstellungsopposition im Mykenischen (ko-to-na kiti-me-na: ke-ke-me-na ko-to-na). Acta classica universitatis Debrecenensis 9, 3-14.

PANAGL, O. (1979): Textual Features in the Linear B Tablets. Colloquium Mycenaeum, Neuchâtel. 313-332.

ŠPELIČ, M. (2002): Grško-slovenski slovar Nove zaveze. Ljubljana 2002.

\section{Wortstellungsforschungen im Altgriechischen \\ Zusammenfassung}

Wenn man heutzutage Wortsstellungsforschungen in einer Korpussprache unternimmt, beklagt man oft die Schwierigkeiten einer derartigen Arbeit. Im Falle des Altgriechischen hätte man eigentlich weniger zu beklagen, denn es mangelt nicht an Material, dazu sind die Texte, die uns zur Verfügung stehen, stilistisch und funktionell verschiedenartig.

Es gibt mehrere Gründe, Wortstellung im Altgriechischen zu untersuchen: stilistische Eigenschaften, das Neugriechische sowie das Verhältnis des Altgriechischen zum Indogermanischen. Es liegt zwar auf der Hand, die Untersuchung auf typologischer Grundlage durchzuführen, die Feststellungen, zu denen man auf diese Weise gelangt, sind jedoch selten schlüssig.

Es ist demnach alles andere als leicht, mit solchen Forschungen zuverlässige Ergebnisse zu erzielen. Die erhaltenen Texte können einen 'native speaker' selbstverständlich nicht ersetzen, zumal die griechischen Grammatiker die Syntax oft bei Seite ließen und die Wortstellungsvarianten der Lehre über den Stil überließen. Ein derartiges Beispiel bieten uns Aristoteles' Poetik und die Abhandlung De compositione verborum des Dionysios von Halikarnas.

Es dürfte uns also kaum überraschen, wenn die Forschungen des 19. und 20. Jahrhunderts sich großenteils mit der Methodologie befaßten.

Naslov:

dr. Matjaž Babǐ̌

Univerza v Ljubljani, Filozofska fakulteta

Aškerčeva 2

SI-1000 Ljubljana

e-mail:matjaz.babic@ff.uni-lj.si 